\title{
THE INFLUENGE OF ACIDOSIS ON CARBOHYDRATE METABOLISM
}

\author{
BY \\ MARY L. GIICHRIST, M.D.*
}

(From the Department of Pædiatrics, Glasgow University, and the Biochemical Laboratory, Royal Hospital for Sick Children, Glasgow.)

In 1922 it was demonstrated by Kaguera ${ }^{1}$ that dogs given a high-fat diet over a certain period of time, showed an abnormal rise in the blood sugar after a glucose meal; and Southwood ${ }^{2}$ in 1923 reported similar results in men who had been given a carbohydrate-free diet for 36 hours previous to the test. Numerous other investigators have confirmed these results, and how striking this hyperglycæmia can be has been demonstrated by me in a previous paper ${ }^{3}$. This reduction in sugar tolerance occurs not only with a carbohydrate-free diet, but also if the subject is deprived of all food; and Severinghaus ${ }^{4}$ has found that after fasting for 48 hours the ingestion of glucose resulted in a blood-sugar reaction resembling that obtained in a mild case of diabetes mellitus.

The chemical changes in the blood which accompany a low carbohydrate diet are in some respects similar to those occurring in starvation, and consist of a non-gaseous acidosis, a diminished alkaline reserve and a ketosis. Some workers have considered that it is the change in acid-base equilibrium which is responsible for the modification in glucose metabolism. Henderson ${ }^{5}$ has pointed out the intimate relationship between acid-base equilibrium and

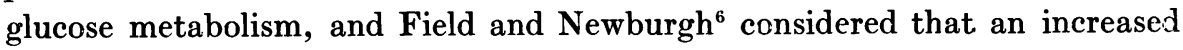
$\mathrm{H}$-ion concentration had a depressing effect on the metabolism of sugar. Langfeldt ${ }^{7}$, by administering acid either orally or intravenously, increased the H-ion concentration of the blood and produced an increased glycogenolysis.

Other hypotheses, however, have been brought forward to explain the change. Du Vigneaud and Karr ${ }^{8}$ and Lennox ${ }^{9}$, who reported results similar

* This work was done during the tenure of a McCunn Medical Research Scholarship. 
to those of Severinghaus ${ }^{4}$, suggested that the lack of carbohydrate was the important factor in producing the disturbance of glucose metabolism which occurred with the change in diet. It has been shown by MacLean and De Wesselow ${ }^{10}$ that a second dose of glucose given as the blood sugar was falling after the rise due to a first, produced no secondary rise in the blood-sugar curve. They explained this by suggesting that the glycogenic function is stimulated by the hyperglycæmia produced by the first dose of glucose, and thus a second rise in blood sugar is prevented. Lennox ${ }^{9}$, therefore, considered it possible that the lack of carbohydrate had deprived the sugardisposing mechanism of the stimulation it required, and he was inclined to believe that this factor was of more importance than the disturbance in acid-base equilibrium.

There seem, therefore, to be three views regarding the disturbance of carbohydrate metabolism in ketosis: (1) That it is due to acidosis per se; (2) that it is due to the action of excess of ketone bodies; or (3) to a diminution in the stores of carbohydrate in the body. If it is due to acidosis pure and simple, the alteration in the $\mathrm{pH}$ of the blood by ammonium chloride should produce the same disturbance as ketosis; but if it is due to the action of ketosis, or merely to carbohydrate starvation, the metabolic disturbance of carbohydrate metabolism should differ from that produced by the drug.

Present investigations.-The investigations described in this paper were designed to throw some further light on this problem. Ammonium chloride, when administered to the normal individual in sufficient quantities, produces a marked disturbance in the acid-base equilibrium, shown by a non-gaseous acidosis and a reduced alkaline reserve, resembling the changes resulting from ingestion of a high-fat low-carbohydrate diet. Haldane ${ }^{11}$ by ingesting large quantities of ammonium chloride caused a profound disturbance of his carbohydrate metabolism manifested by a marked reduction of his glucose tolerance. Lennox ${ }^{9}$ found that a subject with a diminished alkaline reserve $\left(\mathrm{CO}_{2} 44\right.$ vol. per cent.) induced by the daily administration of $20 \mathrm{grm}$. of ammonium chloride for a period of 29 days, showed a curve lower than normal; whereas after a 17 days' fast the blood-sugar curve was diabetic in type though the acidosis was much less than when receiving ammonium chloride. In view of these results it was decided to test whether the metabolic disturbance brought about by ' diet acidosis' differed in any way from that following 'drug acidosis.'

Glucose tolerance during high fat diet. - Fight children, convalescent from chorea or rheumatism (except Case 5 who had been treated for tapeworm) were the subjects of the tests. Their sugar tolerance on ordinary diet was estimated and the results, with those obtained on the special diet, are recorded in Table 1. The children were then given a special high-fat diet for one to two weeks. This diet had a ketogenic anti-ketogenic ratio of 
35 : 1 as calculated from Shaffer's ${ }^{12}$ data. This diet was similar to the one used by Brown and Graham ${ }^{13}$ in their work on ketonæmia and ketonuria, in which they found in every case an increase in the blood acetone accompanied by a fall in the alkaline reserve.

As can be seen from Table 1 and Chart A (demonstrating one case and a composite curve) the glucose tolerance was markedly reduced during the ketogenic-diet periods. The tendency of the blood sugar to remain at a high level at the end of the two hour period is particularly striking though, in contradistinction to the true diabetic curve, it must be noted that thet fasting blood-sugar level was always low.

TABLE 1.

BLOOD-SUGAR CURYES AFTER 1 GRM. OF GLUCOSE PER KGIM. BODY WEITIIT.

\begin{tabular}{|c|c|c|c|c|c|c|c|c|c|c|c|}
\hline \multirow{3}{*}{ Case } & \multirow{3}{*}{$\begin{array}{l}\text { Wt. } \\
\text { kgrm, }\end{array}$} & \multirow{3}{*}{$\begin{array}{c}\text { Amt. } \\
\text { of } \\
\text { Gluc. } \\
\text { grm. }\end{array}$} & \multirow{3}{*}{ Diet } & \multirow{3}{*}{$\begin{array}{c}\text { Dura- } \\
\text { tion } \\
\text { of } \\
\text { fast. } \\
\text { hrs. }\end{array}$} & \multicolumn{6}{|c|}{ Percentage of glucose in blood. } & \multirow{3}{*}{ Urine. } \\
\hline & & & & & \multirow{2}{*}{$\begin{array}{l}\text { Fast. } \\
\text { ing } \\
\text { level. }\end{array}$} & \multicolumn{5}{|c|}{ Minutes after glucose } & \\
\hline & & & & & & 30 & 69 & 90 & 120 & 150 & \\
\hline 1 & 28 & 28 & $\begin{array}{l}\mathrm{N} \\
\mathbf{K}\end{array}$ & $\begin{array}{r}3 \\
15\end{array}$ & $\begin{array}{l}\cdot 106 \\
\cdot 072\end{array}$ & $\begin{array}{l}\cdot 166 \\
\cdot 072\end{array}$ & $\begin{array}{l}\cdot 204 \\
\cdot 168\end{array}$ & $\begin{array}{l}\cdot 189 \\
\cdot 201\end{array}$ & $\begin{array}{l}\cdot 162 \\
\cdot 193\end{array}$ & - & $\begin{array}{l}\text { Nil. } \\
\text { Acetone + ; No sugar }\end{array}$ \\
\hline 2 & 27 & 27 & $\begin{array}{l}\mathrm{N} \\
\mathrm{K}\end{array}$ & $\begin{array}{l}15 \\
15\end{array}$ & $\begin{array}{l}\cdot 109 \\
\cdot 092\end{array}$ & $\begin{array}{l}\cdot 115 \\
\cdot 082\end{array}$ & $\begin{array}{l}\cdot 137 \\
\cdot 134\end{array}$ & $\begin{array}{l}\cdot 141 \\
\cdot 211\end{array}$ & $\begin{array}{l}\cdot 125 \\
\cdot 2 \cdot 21\end{array}$ & $\overline{231}$ & $\begin{array}{l}\text { Nil. } \\
\text { Nosugar : Acetone + }\end{array}$ \\
\hline 3 & 22 & 22 & $\begin{array}{l}\mathrm{N} \\
\mathrm{K}\end{array}$ & $\begin{array}{r}15 \\
8\end{array}$ & $\begin{array}{l}\cdot 095 \\
\cdot 072\end{array}$ & $\begin{array}{l}\cdot 179 \\
\cdot 164\end{array}$ & $\begin{array}{l}\cdot 159 \\
\cdot 224\end{array}$ & $\begin{array}{l}\cdot 129 \\
\cdot 234\end{array}$ & $\begin{array}{l}\cdot 113 \\
\cdot 179\end{array}$ & $\overline{177}$ & $\begin{array}{l}\text { Nil } \\
\text { No sugar : Acetone }+\end{array}$ \\
\hline 4 & 28 & 28 & $\begin{array}{l}\mathrm{N} \\
\mathrm{K}\end{array}$ & $\begin{array}{r}15 \\
8\end{array}$ & $\begin{array}{l}\cdot 100 \\
\cdot 062\end{array}$ & $\begin{array}{l}\cdot 125 \\
\cdot 075\end{array}$ & $\begin{array}{l}\cdot 152 \\
\cdot 148\end{array}$ & $\begin{array}{l}\cdot 109 \\
\cdot 159\end{array}$ & $\begin{array}{l}\cdot 121 \\
\cdot 162\end{array}$ & - & $\begin{array}{l}\text { Nil. } \\
\text { No sugar: Acetone + }\end{array}$ \\
\hline 5 & 24 & 24 & $\begin{array}{l}\mathrm{N} \\
\mathrm{K}\end{array}$ & $\begin{array}{l}8 \\
8\end{array}$ & $\begin{array}{l}\cdot 119 \\
\cdot 077\end{array}$ & $\begin{array}{l}\cdot 204 \\
\cdot 134\end{array}$ & $\begin{array}{l}\cdot 196 \\
\cdot 182\end{array}$ & $\begin{array}{l}\cdot 158 \\
\cdot 2: 21\end{array}$ & $\begin{array}{l}\cdot 111 \\
\cdot 187\end{array}$ & - & $\begin{array}{l}\text { Nil. } \\
\text { No sugar: Acetone }+\end{array}$ \\
\hline 6 & 27 & 27 & $\begin{array}{l}\mathrm{N} \\
\mathrm{K}\end{array}$ & 15 & $\begin{array}{l}\cdot 113 \\
\cdot 072\end{array}$ & $\begin{array}{l}\cdot 137 \\
\cdot 103\end{array}$ & $\begin{array}{l}\cdot 147 \\
\cdot 159\end{array}$ & $\begin{array}{l}\cdot 141 \\
\cdot 141\end{array}$ & $\begin{array}{l}\cdot 109 \\
\cdot 162\end{array}$ & - & $\begin{array}{l}\text { Nil. } \\
\text { No sugar: Acet. trace }\end{array}$ \\
\hline 7 & 25 & 25 & $\begin{array}{l}\mathrm{N} \\
\mathrm{K}\end{array}$ & $\begin{array}{l}15 \\
15\end{array}$ & $\cdot 127$ & $\begin{array}{l}\cdot 181 \\
\cdot 16 \cdot 2\end{array}$ & $\begin{array}{l}\cdot 189 \\
\cdot 218\end{array}$ & $\begin{array}{l}\cdot 123 \\
\cdot 206\end{array}$ & $\begin{array}{l}\cdot 141 \\
\cdot 177\end{array}$ & - & $\begin{array}{l}\text { Nil. } \\
\text { Acetone }+ \text { : No sugar }\end{array}$ \\
\hline 8 & 25 & 25 & $\begin{array}{l}\mathrm{N} \\
\mathrm{K}\end{array}$ & $?$ & $\begin{array}{l}\cdot 097 \\
\cdot 104\end{array}$ & $\begin{array}{l}\cdot 114 \\
\cdot 191\end{array}$ & $\begin{array}{l}\cdot 093 \\
\cdot 251\end{array}$ & $\begin{array}{l}\cdot 113 \\
\cdot 247\end{array}$ & $\begin{array}{l}\cdot 113 \\
\cdot 162\end{array}$ & - & $\begin{array}{l}\text { Nil. } \\
\text { Acetone + }\end{array}$ \\
\hline
\end{tabular}

N. = Normal diet.

K. = Ketogenic diet. 
CHART A.

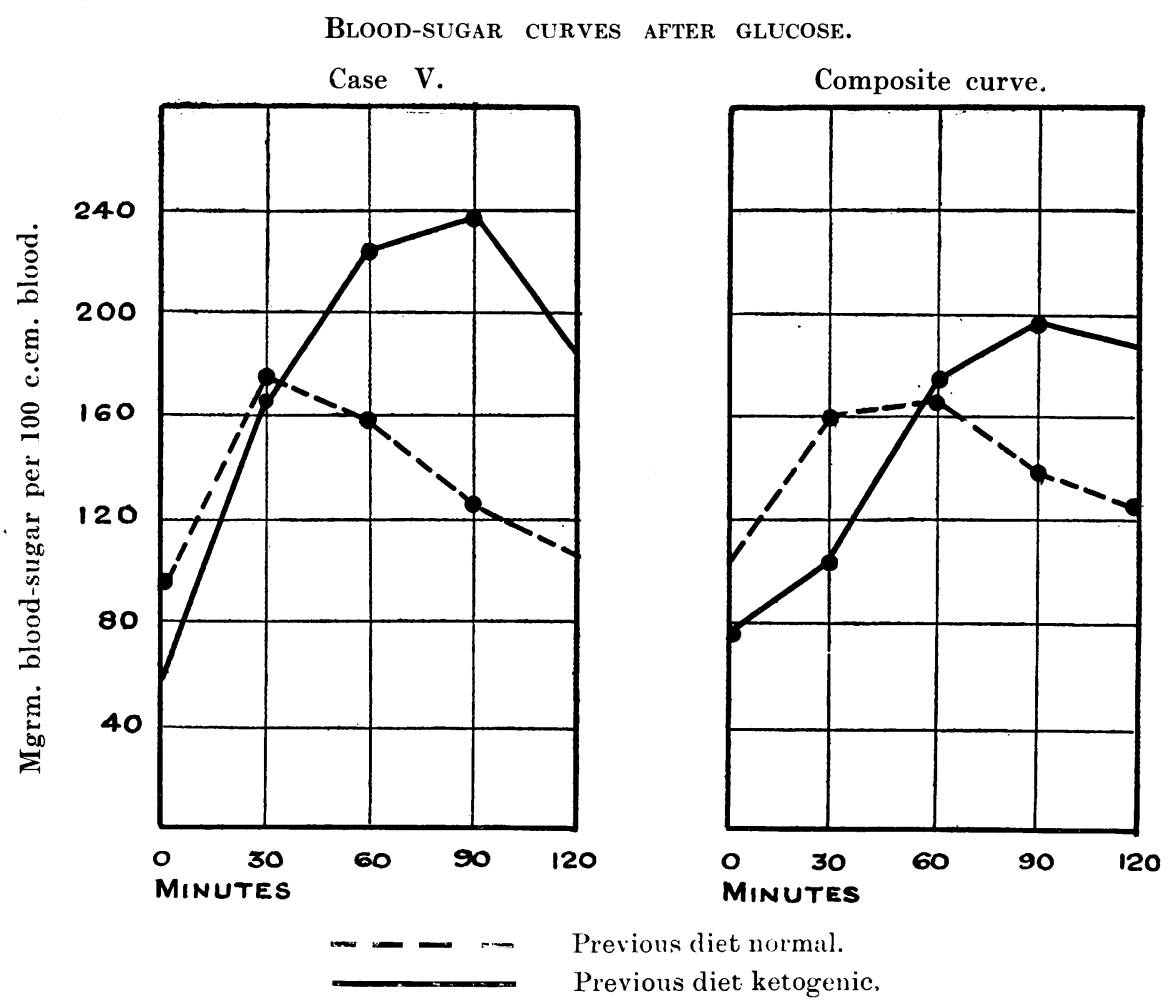

Glucose tolerance after ammonium chloride. - The sugar tolerance of nine children, four of whom were also subjects of the previous test, was examined after the administration of ammonium chloride. The normal glucose tolerance was estimated in those not previously investigated, and thereafter the children were given ammonium chloride for varying periods of time. The details of the experiment are set out more fully below as each case comes to be discussed. The quantity of ammonium chloride given was approximately equivalent to the amount which Haldane ${ }^{11}$ used. The children, who were more or less of the same weight, were all given $1 \mathrm{grm}$. of the drug in capsule form five times a day before meals.

The results were, however, so much less consistent than those obtained from the ketogenic diet that various changes in the diet and the duration of administration of the drug were made with a view to obtaining more uniform results, but it was found that those changes had no effect. The results are tabulated in Table 2.

Cases 1 and 7 were given ammonium chloride for four days and both showed an increased tolerance for glucose, the curve being lower and the value returning sooner to fasting than on normal diet. On ketogenic diet both these cases showed a reduced tolerance for glucose. That the condition of acidosis had been definitely established by the fourth day can be seen from 
TABI,E 2.

Blood-SUgar curves after the administration of $\mathrm{NH}_{4} \mathrm{Cl}$.

\begin{tabular}{|c|c|c|c|c|c|c|c|c|c|}
\hline \multirow[b]{2}{*}{ Case. } & \multirow[b]{2}{*}{$\begin{array}{l}\text { A.mt. of } \\
\text { glu乞ose } \\
\text { grm. }\end{array}$} & \multirow[b]{2}{*}{$\begin{array}{l}\text { Diet } \\
\text { and } \\
\text { drugs. }\end{array}$} & \multirow[b]{2}{*}{$\begin{array}{l}\text { No. of } \\
\text { days on } \\
\text { am. } \\
\text { chlor. }\end{array}$} & \multicolumn{5}{|c|}{ Percentage glucose in blood. } & \multirow[b]{2}{*}{ Urine. } \\
\hline & & & & $\begin{array}{l}\text { Fast- } \\
\text { ing } \\
\text { level. }\end{array}$ & Min & $\begin{array}{c}\text { tes af } \\
60\end{array}$ & $\begin{array}{l}\text { er glu } \\
90\end{array}$ & $\begin{array}{l}\text { ose. } \\
120\end{array}$ & \\
\hline l & 28 & $\stackrel{\mathrm{N}}{\mathrm{N}}+\mathrm{NH}_{4} \mathrm{C} !$ & $\overline{4}$ & $\begin{array}{l}\cdot 106 \\
\cdot 104\end{array}$ & $\begin{array}{l}\cdot 166 \\
\cdot 144\end{array}$ & $\begin{array}{l}\cdot 204 \\
\cdot 164\end{array}$ & $\begin{array}{l}\cdot 189 \\
\cdot 104\end{array}$ & $\begin{array}{l}\cdot 162 \\
\cdot 082\end{array}$ & $\begin{array}{l}\text { Nil. } \\
\text { Nil. }\end{array}$ \\
\hline 2 & 27 & $\begin{array}{l}\mathrm{N} \\
\mathrm{N}+\mathrm{S}+\mathrm{NH}_{4} \mathrm{Cl}\end{array}$ & $\overline{7}$ & $\begin{array}{l}\cdot 109 \\
\cdot 113\end{array}$ & $\begin{array}{l}\cdot 115 \\
\cdot 181\end{array}$ & $\begin{array}{l}\cdot 137 \\
\cdot 211\end{array}$ & $\begin{array}{l}\cdot 141 \\
\cdot 172\end{array}$ & $\begin{array}{l}\cdot 125 \\
\cdot 141\end{array}$ & $\begin{array}{l}\text { Nil. } \\
\text { Sugar + + }\end{array}$ \\
\hline 7 & 25 & $\begin{array}{l}\mathrm{N} \\
\mathrm{O}+\mathrm{NH}_{4} \mathrm{Cl}\end{array}$ & - & $\begin{array}{l}\cdot 127 \\
\cdot 058\end{array}$ & $\begin{array}{l}\cdot 181 \\
\cdot 154\end{array}$ & $\begin{array}{l}\cdot 189 \\
\cdot 134\end{array}$ & $\begin{array}{l}\cdot 123 \\
\cdot 077\end{array}$ & $\begin{array}{l}\cdot 141 \\
\cdot 041\end{array}$ & $\begin{array}{l}\text { Nil. } \\
\text { Nil. }\end{array}$ \\
\hline 8 & 25 & $\begin{array}{l}\mathrm{N} \\
\mathrm{Milk} \\
\mathrm{N}+\mathrm{NH}_{4} \mathrm{Cl} \\
\mathrm{N}+\mathrm{NH}_{4} \mathrm{Cl} \\
\mathrm{N}+\mathrm{NH}_{4} \mathrm{Cl}\end{array}$ & $\begin{array}{r}- \\
\overline{8} \\
16 \\
24\end{array}$ & $\begin{array}{l}\cdot 129 \\
\cdot 100 \\
\cdot 109 \\
\cdot 104 \\
\cdot 115\end{array}$ & $\begin{array}{l}\cdot 181 \\
\cdot 1: 2 \\
\cdot 207 \\
\cdot 161 \\
\cdot 209\end{array}$ & $\begin{array}{l}\cdot 196 \\
\cdot 177 \\
\cdot 177 \\
\cdot 157 \\
\cdot 254\end{array}$ & $\begin{array}{l}\cdot 141 \\
\cdot 129 \\
\cdot 122 \\
\cdot 166 \\
\cdot 164\end{array}$ & $\begin{array}{l}\cdot 131 \\
\cdot 104 \\
\cdot 100 \\
\cdot 095 \\
\cdot 107\end{array}$ & $\begin{array}{l}\text { Nil. } \\
\text { Nil. } \\
\text { Nil. } \\
\text { Nil. } \\
\text { Nil. }\end{array}$ \\
\hline 9 & 20 & $\begin{array}{l}\mathrm{N} \\
\mathrm{M}+\mathrm{S}+\mathrm{NH}_{4} \mathrm{Cl}\end{array}$ & $\overline{7}$ & $\begin{array}{l}\cdot 156 \\
\cdot 134\end{array}$ & $\begin{array}{l}\cdot 186 \\
\cdot 26 !\end{array}$ & $\begin{array}{l}\cdot 147 \\
\cdot 206\end{array}$ & $\begin{array}{l}\cdot 162 \\
\cdot 196\end{array}$ & $\begin{array}{l}\cdot 129 \\
\cdot 181\end{array}$ & $\begin{array}{l}\text { Nil. } \\
\text { Trace sugar }\end{array}$ \\
\hline 10 & 21 & $\stackrel{\mathrm{N}}{\mathrm{M}}+\mathrm{S}+\mathrm{NH}_{+} \mathrm{Cl}$ & $\overline{13}$ & $\begin{array}{l}.077 \\
.085\end{array}$ & $\begin{array}{l}\cdot 137 \\
\cdot 134\end{array}$ & $\begin{array}{l}\cdot 157 \\
\cdot 137\end{array}$ & $\begin{array}{l}\cdot 152 \\
\cdot 152\end{array}$ & $\begin{array}{l}\cdot 113 \\
\cdot 134\end{array}$ & $\begin{array}{l}\text { Nil. } \\
\text { Nil. }\end{array}$ \\
\hline 11 & 16 & $\stackrel{\mathrm{N}}{\mathrm{N}}+\mathrm{NH}_{4} \mathrm{Cl}$ & $\overline{8}$ & $\cdot 085$ & $\begin{array}{l}\cdot 129 \\
\cdot 209\end{array}$ & $\begin{array}{l}160 \\
\cdot 201\end{array}$ & $\begin{array}{l}\cdot 139 \\
\cdot 117\end{array}$ & $\begin{array}{l}\cdot 113 \\
\cdot 067\end{array}$ & $\begin{array}{l}\text { Nil. } \\
\text { Nil. }\end{array}$ \\
\hline 12 & 26 & $\begin{array}{l}\mathrm{N} \\
\text { Milk } \\
\mathrm{N}+\mathrm{NH}_{4} \mathrm{Cl} \\
\mathrm{M}+\mathrm{NH}_{4} \mathrm{Cl}\end{array}$ & $\begin{array}{c}- \\
8 \\
7\end{array}$ & $\begin{array}{l}\cdot 109 \\
\cdot 084 \\
\cdot 109 \\
\cdot 077\end{array}$ & $\begin{array}{l}\cdot 175 \\
\cdot 193 \\
\cdot 172 \\
\cdot 184\end{array}$ & $\begin{array}{l}\cdot 147 \\
\cdot 206 \\
\cdot 234 \\
\cdot 189\end{array}$ & $\begin{array}{l}\cdot 134 \\
\cdot 150 \\
\cdot 189 \\
\cdot 182\end{array}$ & $\begin{array}{l}\cdot 113 \\
\cdot 063 \\
\cdot 085 \\
\cdot 109\end{array}$ & $\begin{array}{l}\text { Nil. } \\
\text { Nil. } \\
\text { Nil. } \\
\text { Nil. }\end{array}$ \\
\hline 13 & $\begin{array}{l}18 \\
.\end{array}$ & $\begin{array}{l}\mathrm{N} \\
\mathrm{N}+\mathrm{NH}_{4} \mathrm{Cl} \\
\mathrm{N}+\mathrm{NH}_{4} \mathrm{Cl} \\
\mathrm{N}+\mathrm{NH}_{4} \mathrm{Cl} \\
\mathrm{M}+\mathrm{NH}_{4} \mathrm{Cl} \\
\mathrm{Milk}\end{array}$ & $\begin{array}{r}- \\
6 \\
18 \\
24 \\
32 \\
-\end{array}$ & $\begin{array}{l}\cdot 095 \\
\cdot 109 \\
\cdot 092 \\
\cdot 113 \\
\cdot 109 \\
\cdot 096\end{array}$ & $\begin{array}{l}\cdot 137 \\
\cdot 149 \\
\cdot 141 \\
\cdot 152 \\
\cdot 174 \\
\cdot 132\end{array}$ & $\begin{array}{l}\cdot 177 \\
\cdot 152 \\
\cdot 157 \\
\cdot 1 \times 6 \\
\cdot 204 \\
\cdot 132\end{array}$ & $\begin{array}{l}\cdot 116 \\
\cdot 129 \\
\cdot 152 \\
\cdot 162 \\
\cdot 194 \\
\cdot 077\end{array}$ & $\begin{array}{l}\cdot 100 \\
\cdot 081 \\
\cdot 113 \\
\cdot 117 \\
\cdot 121 \\
\cdot 072\end{array}$ & $\begin{array}{l}\text { Nil. } \\
\text { Nil. } \\
\text { Nil. } \\
\text { Nil. } \\
\text { Nil. } \\
\text { Nil. }\end{array}$ \\
\hline
\end{tabular}

$\mathrm{N}=$ Normal diet.

$\mathbf{M}=$ Milk diet equal to caloric requirements.

$\mathrm{M}+\mathrm{S}=\mathrm{Milk}$ and sugar equal to caloric requirements. 
Table 3 which shows the change in the $\mathrm{CO}_{2}$ content of the blood in three of the cases.

TABLE 3.

\begin{tabular}{|c|c|c|}
\hline $\begin{array}{l}\text { Case No. } 2 . \\
\text { Normal. } \\
4 \text { days on } \\
8 \text {,, , }\end{array}$ & $\begin{array}{c}\mathrm{NH}_{4} \mathrm{Cl} . \\
,,\end{array}$ & $\begin{array}{c}\mathrm{CO}_{2} \text { Vol. \%. } \\
68 \cdot 2 \\
41 \cdot 4 \\
40 \cdot 3\end{array}$ \\
\hline \multicolumn{3}{|l|}{ Case No. 7.} \\
\hline \begin{tabular}{ccc}
\multicolumn{3}{c}{ Normal. } \\
3 & days & on \\
6 &,, &,, \\
9 &, &,, \\
13 &, &,,
\end{tabular} & $\begin{array}{c}\mathrm{NH}_{4} \mathrm{Cl} . \\
,, \\
,\end{array}$ & $\begin{array}{l}60 \cdot 6 \\
45 \cdot 1 \\
41 \cdot 8 \\
43 \cdot 4 \\
45 \cdot 0\end{array}$ \\
\hline \multicolumn{3}{|l|}{ Case No. 10.} \\
\hline $\begin{array}{l}\text { Normal. } \\
9 \text { days on } \\
19 \text {, , , }\end{array}$ & $\begin{array}{c}\mathrm{NH}_{4} \mathrm{Cl} . \\
,,\end{array}$ & $\begin{array}{l}66 \cdot 7 \\
49 \cdot 1 \\
45 \cdot 8\end{array}$ \\
\hline
\end{tabular}

It is obvious that the acidosis produced by ammonium chloride had not in Cases 1 and 7 reduced the tolerance for glucose.

Cases 2, 9 and 10 were given for 10 days previous to the test, a milk diet plus $40 \mathrm{grm}$. of sugar daily, the diet containing an adequate caloric content for their respective weights. Then for seven days in Cases 2 and 9, and for 13 days in Case 10, ammonium chloride was administered, and the sugar tolerance then estimated. In Cases 2 and 9 a markedly reduced tolerance was noted and glycosuria occurred in both cases, though in Case 2 the hyperglycæmia was not as prolonged as that produced by the ketogenic diet. In Case 10 no change occurred.

Cases 11, 12 and 8 were given ammonium chloride for eight days, and Cases 11 and 12 showed a definite reduction and Case 8 a slight reduction in tolerance. At the end of 16 days of ammonium chloride administration Case 8 showed an increased tolerance for glucose though, as shown by Case 10, the acidosis from ammonium chloride lasts longer than this. Cases 12 and 13 were given, next, a milk diet without the addition of sugar but the administration of the drug was continued. Case 12 showed no change, but Case 13 gave a definitely higher curve than before, although not as high as that obtained on a ketogenic diet. After 32 days on the drug Case 13 showed little change in the tolerance for glucose.

Only two of the cases (No. 2 and 9) showed curves at all comparable to those found with ketogenic diet. In the others there was a slight reduction in the tolerance for glucose, but there was no delay in the return to fasting level, a feature which is so characteristic of the diabetic curve obtained on a high-fat diet. 
These experiments show that compared with the disturbance which is the result of a high-fat low-carbohydrate diet the acidosis produced by ammonium chloride damages but slightly the ability of the organism to utilize carbohydrate.

In a case (A. F.) of severe clinical acidosis treated in the Royal Hospital for Sick Children the blood sugar (after glucose) was 331 per cent. and the $\mathrm{CO}_{2}$ was 30 vol. per cent. The next day when the acidosis had gone, the $\mathrm{CO}_{2}$ being 72 vol. per cent., the blood sugar after glucose was still high, $\cdot 299$ per cent., so that the return of the acid base balance to normal had not restored the ability of the tissues to utilize glucose.

It seems, therefore, that non-gaseous acidosis is not in itself the cause of the disturbance in the glycogenic function.

Action of insulin and adrenalin in ketosis.-There is a difference in the acidosis which is produced by ammonium chloride and that produced by a ketogenic diet. The latter is accompanied by acetonuria, acetone in varying amounts appearing in the urine throughout the period of administration of the drug. It has been shown that no matter how small the quantity of acetone in the urine there is an accompanying acetonæmia, and it may be that this acetonæmia plays a part in the disturbance of the metabolism. Von Noorden ${ }^{14}$ observed that glycosuria and hyperglycæmia occurred after the administration of acetone; and Morris and Graham ${ }^{15}$ found that rabbits, injected with 20 per cent. acetone, showed a slight increase in the sugar content of the blood.

Severinghaus ${ }^{4}$ has put forward the suggestion that ketosis inhibits the production or the action of insulin, and it would seem from the above experiment that there may be grounds for this belief. This point was tested by the following experiments.

The subjects, whose reaction to glucose both on normal and ketogenic diets was known, were each given 5 units of insulin while in the postabsorptive state, and the blood sugar estimated 10, 30, 60, 90 and 120 minutes after the injection.

On normal diet 5 units of insulin produced a very slight fall in the blood sugar. The results are tabulated in Table 4 and Chart $B$. If the reaction to insulin on normal diet was slight, the response after ketogenic diet was striking. In all but one of the cases hypoglycæmia was marked and in three definite symptoms were noted.

The length of time the subject was on ketogenic diet had but little bearing on the reaction and Case 4 gave two practically parallel curves, though one was performed on the seventh day and the other on the twelfth day from the commencement of the diet. The resultant hypoglycæmia was but little influenced also by the level of the fasting blood sugar as is shown by the figures given in Table 5 .

This fact has been commented upon by Macleod ${ }^{16}$ who demonstrated in rabbits that the level of the blood sugar existing at the time of the injection 
TABLE 4.

BLOOD-SUGAR CLRVES AFTLR INSULIN.

\begin{tabular}{|c|c|c|c|c|c|c|c|c|c|c|c|c|}
\hline \multirow{3}{*}{ Case } & \multirow{3}{*}{$\begin{array}{l}\text { Age } \\
\text { yr. }\end{array}$} & \multirow{3}{*}{$\begin{array}{l}\text { Units } \\
\text { of in- } \\
\text { sulin }\end{array}$} & \multirow{3}{*}{ Diet } & \multicolumn{7}{|c|}{ Percentage glucose in blood. } & \multirow{3}{*}{$\begin{array}{l}\text { Fall in } \\
\text { blood } \\
\text { sugar } \\
\text { mgrm. }\end{array}$} & \multirow{3}{*}{ Urine } \\
\hline & & & & \multirow{2}{*}{$\begin{array}{l}\text { Fast. } \\
\text { ing } \\
\text { level }\end{array}$} & \multicolumn{6}{|c|}{ Minutes after insulin } & & \\
\hline & & & & & 10 & 30 & 60 & 90 & 120 & 150 & & \\
\hline 1 & 12 & 5 & $\begin{array}{l}\mathrm{N} \\
\mathrm{K}\end{array}$ & $\begin{array}{l}\cdot 104 \\
\cdot 075\end{array}$ & $\begin{array}{l}\cdot 094 \\
.060\end{array}$ & $\begin{array}{l}\cdot 100 \\
\cdot 042\end{array}$ & $\begin{array}{l}\cdot 094 \\
\cdot 042\end{array}$ & $\overline{040}$ & $\begin{array}{l}\cdot 089 \\
\cdot 064\end{array}$ & - & $\begin{array}{l}10 \\
3 \tilde{5}\end{array}$ & $\begin{array}{l}\text { Nil. } \\
\text { Acetone + + }\end{array}$ \\
\hline 2 & 10 & 5 & $\begin{array}{l}\mathrm{N} \\
\mathrm{K}\end{array}$ & $\cdot 107$ & $\begin{array}{l}\cdot 104 \\
\cdot 083\end{array}$ & $\begin{array}{l}\cdot 087 \\
\cdot 065\end{array}$ & $\begin{array}{l}\cdot 100 \\
\cdot 069\end{array}$ & $\begin{array}{l}\cdot 109 \\
\cdot 053\end{array}$ & $\cdot 055^{*}$ & $\overline{.030}$ & $\begin{array}{l}20 \\
72\end{array}$ & $\begin{array}{l}\text { Nil. } \\
\text { Acetone + + }\end{array}$ \\
\hline 3 & 10 & 5 & $\begin{array}{l}\mathrm{N} \\
\mathrm{N} \\
\mathrm{K} \\
\mathrm{K}\end{array}$ & $\begin{array}{l}\cdot 103 \\
\cdot 082 \\
\cdot 067 \\
\cdot 0 ; 7\end{array}$ & $\begin{array}{l}\cdot 125 \\
\cdot 094 \\
\cdot 063 \\
\cdot 077\end{array}$ & $\begin{array}{l}\cdot 100 \\
\cdot 075 \\
\cdot 067 \\
\cdot 066\end{array}$ & $\begin{array}{l}\cdot 094 \\
\cdot 097 \\
\cdot 056 \\
\cdot 058\end{array}$ & $\begin{array}{l}\cdot 100 \\
\cdot 072 \\
\cdot 063 \\
\cdot 065\end{array}$ & $\begin{array}{l}- \\
\cdot 084 \\
.063 \\
-\end{array}$ & $\overline{-}$ & $\begin{array}{c}\text { (rise) } \\
22 \\
11 \\
10\end{array}$ & $\begin{array}{l}\text { Nil. } \\
\text { Nil. } \\
\text { Acetone + } \\
\text { Acetone + }\end{array}$ \\
\hline 4 & 11 & 5 & $\begin{array}{l}\mathrm{N} \\
\mathrm{N} \\
\mathrm{K}\end{array}$ & $\begin{array}{l}\cdot 090 \\
\cdot 104 \\
\cdot 100\end{array}$ & $\begin{array}{l}\cdot 117 \\
\cdot 102 \\
\cdot 091\end{array}$ & $\begin{array}{l}\cdot 104 \\
\cdot 067 \\
\cdot 081\end{array}$ & $\begin{array}{l}\cdot 090 \\
\cdot 082 \\
\cdot 077\end{array}$ & $\begin{array}{l}\cdot 094 \\
\cdot 082 \\
\cdot 055\end{array}$ & $\begin{array}{l}-\overline{-} \\
-0(i !)\end{array}$ & - & $\begin{array}{c}\text { (rise) } \\
37 \\
45\end{array}$ & $\begin{array}{l}\text { Nil. } \\
\text { Nil. } \\
\text { Acetone + }\end{array}$ \\
\hline 5 & 12 & 5 & $\begin{array}{l}\mathrm{N} \\
\mathrm{K}\end{array}$ & $\begin{array}{l}\cdot 116 \\
\cdot 092\end{array}$ & $\begin{array}{l}\cdot 100 \\
\cdot 094\end{array}$ & $\begin{array}{l}\cdot 087 \\
\cdot 072\end{array}$ & $\begin{array}{l}\cdot 089 \\
.077\end{array}$ & $\begin{array}{l}\cdot 094 \\
075\end{array}$ & $\begin{array}{l}\cdot 104 \\
.075\end{array}$ & - & $\begin{array}{l}39 \\
20\end{array}$ & $\begin{array}{l}\text { Nil. } \\
\text { Acetone + }\end{array}$ \\
\hline 6 & 11 & 5 & $\begin{array}{l}\mathrm{N} \\
\mathrm{K}\end{array}$ & $\begin{array}{l}.082 \\
.081\end{array}$ & $\begin{array}{l}\cdot 089 \\
\cdot 072\end{array}$ & $\begin{array}{l}\cdot 084 \\
\cdot 042\end{array}$ & $\begin{array}{l}.077 \\
042\end{array}$ & $\begin{array}{l}\cdot 082 \\
\cdot 035\end{array}$ & - & - & $\begin{array}{r}5 \\
46\end{array}$ & $\begin{array}{l}\text { Nil. } \\
\text { Acetone + }\end{array}$ \\
\hline 7 & 9 & 5 & $\begin{array}{l}\mathrm{N} \\
\mathrm{K}\end{array}$ & $\begin{array}{l}\cdot 089 \\
\cdot 064\end{array}$ & $\begin{array}{l}\cdot 089 \\
\cdot 058\end{array}$ & $\begin{array}{l}\cdot 077 \\
\cdot 053\end{array}$ & $\begin{array}{l}\cdot 089 \\
\cdot 052\end{array}$ & $\begin{array}{l}\cdot 085 \\
\cdot 048\end{array}$ & .043 & - & $\begin{array}{l}12 \\
21\end{array}$ & Nil. \\
\hline Co & Curvo & $\begin{array}{l}\text { site } \\
\text { e. }\end{array}$ & $\begin{array}{l}\mathrm{N} \\
\mathrm{K}\end{array}$ & $\begin{array}{l}\cdot 097 \\
\cdot 081\end{array}$ & $\begin{array}{l}\cdot 100 \\
\cdot 075\end{array}$ & $\begin{array}{c}\cdot 086 \\
\cdot 059\end{array}$ & $\begin{array}{c}\cdot 090 \\
\cdot 059\end{array}$ & $\begin{array}{c}\cdot 092 \\
\cdot 061\end{array}$ & - & - & $\frac{9}{27}$ & - \\
\hline
\end{tabular}

* Hypoglycremic symptoms. $\quad \mathrm{N}=$ Normal diet. $\mathrm{K}=$ Ketogenic diet.

CHART B.

Blood-sugar CURVES aFter insulin.

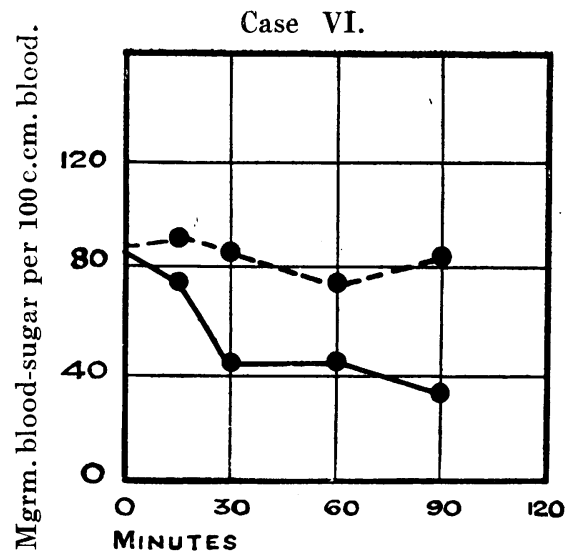

Composite curve.

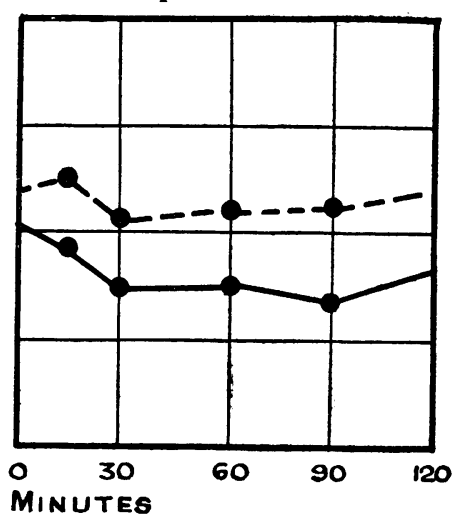

Previous diet normal.

Previous diet ketogenic. 
of insulin and the steepness of the initial fall in the blood sugar are not related unless the fasting level be very high when the descent becomes more rapid.

TABILE 5

Fall of blood sugar after insulin.

\begin{tabular}{|c|c|c|c|c|c|c|c|c|c|c|c|c|c|}
\hline \multirow{2}{*}{ Case } & \multicolumn{6}{|c|}{ Blood sugar } & \multirow{2}{*}{ Case } & \multicolumn{6}{|c|}{ Blood sugar } \\
\hline & \multicolumn{3}{|c|}{ Fasting } & \multicolumn{3}{|c|}{ Lowest value } & & \multicolumn{3}{|c|}{ F'asting } & \multicolumn{3}{|c|}{ Lowest value } \\
\hline 1 & $\cdot 075$ & ngr & $\%$ & $\cdot 040$ & ngrm. & $\%$ & 5 & 092 & $n g$ &.$\%$ & $\cdot 072$ & ng & \\
\hline 2 & $\cdot 102$ &, &., & $\cdot 030$ & ., & & 6 & $\cdot 081$ & , & & $\cdot 035$ & , & , \\
\hline 3 & .067 & , & , , & $\cdot 056$ & , , & , , & 7 & $\cdot 06$ & ,. &, & $\cdot 043$ & , &, \\
\hline 4 & $\cdot 100$ &, & , & $\cdot 055$ & , & , & & & & & & & \\
\hline
\end{tabular}

Case 3, who reacted very slightly both on normal and on special diet, seemed to possess a tolerance for insulin shown by none of the others.

It is clear that the presence of ketonæmia as indicated by ketonuria does not inhibit the action of insulin. Since the action of adrenalin and insulin are so closely concerned in the metabolism of carbohydrate the action of adrenalin during the ingestion of a ketogenic diet was also investigated in the same cases.

The smallest quantity of adrenalin chloride (1/1,000 sol. B.W. \& Co.) which caused a rise in the blood sugar of children of different ages has been worked out at the Royal Hospital for Sick Children by Dr. Isobel Mitchell. It was found that the quantity of adrenalin necessary depended on the age of the child (Table 6).

TABLE 6.

\begin{tabular}{|c|c|}
\hline Age of child & Amount of adrenalin \\
\hline 1 year & $1 \mathrm{minim}$ \\
\hline 2 years & 2 minims \\
\hline $3,4,5,6,7$ years & $3 \quad$, \\
\hline 8 years & 4. , , \\
\hline $9,10,11$ years & $5 \quad \ldots$ \\
\hline 12. years & $6 \quad .$. \\
\hline
\end{tabular}

In the work detailed below the amounts of adrenalin used were based on this standard. The injections were subcutaneous and the blood for the estimations was taken before and 10, 30, 60, 90 and 120 minutes after the injection. 
TABLE 7 .

Brood-Stiak CURVES AFTKR ADRENaIIN.

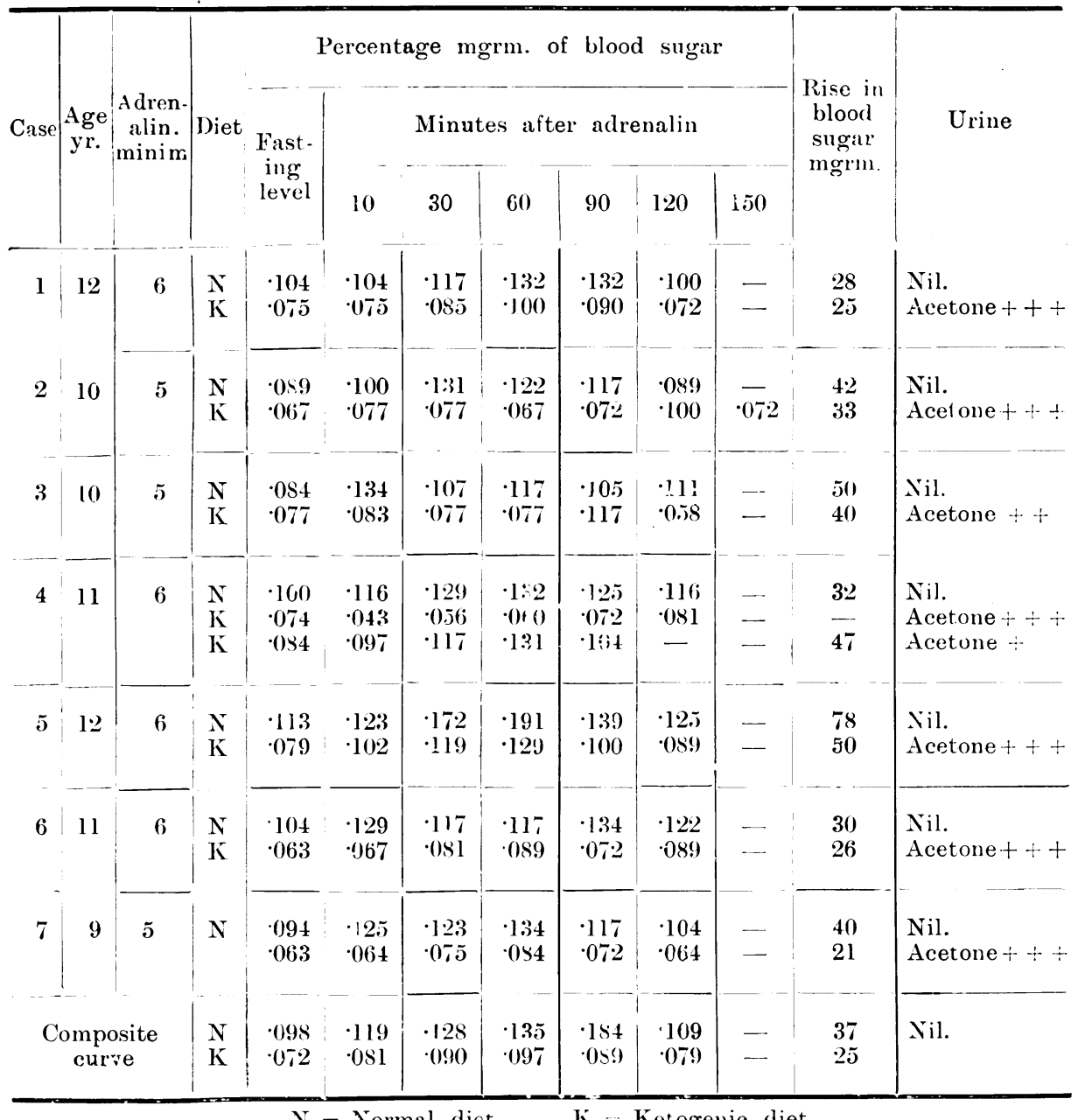

$\mathrm{N}=$ Normal diet. $\mathrm{K}=$ Ketogenic diet.

CHART C.

Blood-sugar curves aFter adRENalin.

Case VII.

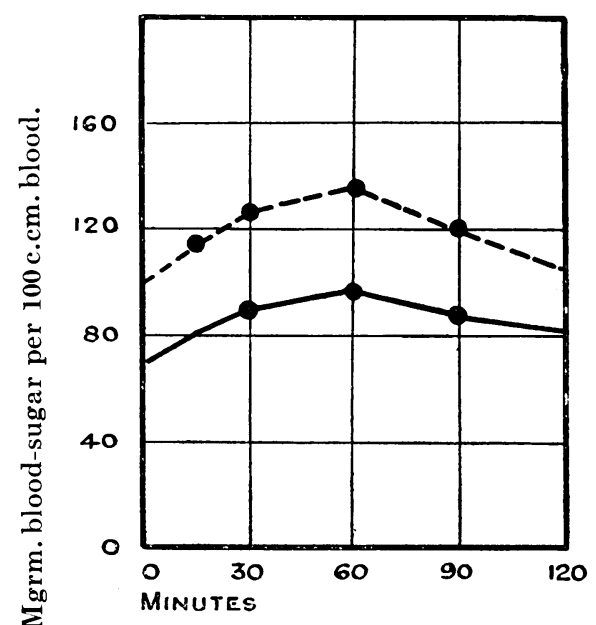

Composite curve.

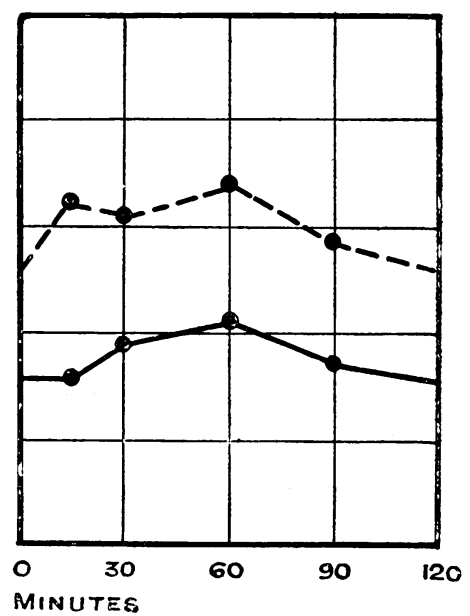


All seven cases, under ordinary dietary conditions, showed the normal response after the injection of adrenalin, the hyperglycæmia being appreciable and sustained for at least $1 \frac{1}{2}$ hours. The results obtained while the children were receiving ketogenic diet were quite different. The blood sugar did not rise so high above the fasting level nor was the hyperglycæmia so sustained, indicating that the release of glycogen was less than when the subjects were on ordinary diet. From these results it seems clear that the actions of insulin and adrenalin are definitely modified by ketogenic diet.

\section{Discussion.}

Our results show that the acidosis produced by the administration of ammonium chloride does not cause any notable disturbance of carbohydrate metabolism, while in that associated with ketosis there is a definite disturbance, manifested not only by sugar-tolerance tests but also by the reactions to insulin and adrenalin. Probabiy, then, acidosis in itself is not the disturbing factor. This conclusion is supported by the work of Ellis ${ }^{17}$ who found that administration of sodium bicarbonate with ketogenic diet did not lessen the intolerance to glucose. It may be, however, that ketone bodies circulating in the blood are responsible for the alteration in sugar tolerance, but there is another possibility which requires consideration. In the production of ketosis it is necessary to reduce the carbohydrate intake to a minimum and consequently to reduce the store of carbohydrate in the liver and tissues, and it may be that the disturbance of carbohydrate metabolism which has been found to occur in subjects on ketogenic diet is due not to ketosis but to depletion of carbohydrate stores. Certain findings by other workers are worth considering in this connexion. Stewart and Rogoff ${ }^{18}$ showed that prolonged action of insulin is not due to any inhibition of the adrenals since complete removal of these glands in rabbits did not affect the action of insulin. MacLeod and others ${ }^{19}$ found that in rabbits the richer the glycogen content of the liver the more resistant were they to insulin. Lawrence ${ }^{20}$ has pointed out that in patients suffering from diabetes mellitus insulin is much more effective when the glycogen store is low. From the work of Mann and Magath ${ }^{21}$ and Burn and Marks ${ }^{22}$ it can be concluded that the hyperglycæmia which occurs after the injection of adrenalin is dependent upon the amount of liver glycogen.

These findings suggest that the enhanced effect of insulin and the diminished action of adrenalin are due to depleted stores of carbohydrate rather than to the presence of ketonæmia. It would also seem fair to infer that the effect of ketogenic diet in producing an alteration in carbohydrate metabolism is due chiefly to the diminution in the glycogen content of the liver. If this be true it offers an explanation of the difference in the reaction to the acidosis produced by ammonium chloride and that induced by ketogenic diet. 


\section{Summary}

The effect of ketogenic diet on the blood-sugar curve following glucose ingestion is to cause a rise greater than normal and a delay in the return to the fasting level. The fasting blood sugar is generally definitely lowered when the subject is on ketogenic diet.

Ammonium-chloride ingestion occasionally produces a change in the blood-sugar curve, but the change is much less marked than that produced by ketogenic diet.

The action of insulin is augmented and the effect of adrenalin diminished when the previous diet is ketogenic.

It is suggested that the alteration in the carbohydrate metabolism caused by ketogenic diet is not due to acidosis but to diminution in stores of carbohydrate produced by this diet.

I desire to record my thanks to Dr. Leonard Findlay at whose suggestion this research was undertaken.

\section{REFERENGES.}

1. Kaguera, N., J. Biochem., Tokyo, 1922, I, 333. (Quoted by Greenwald, Gross \& Samet, J. Biol. Chem., Baltimore, 1924, LXII, 401.)

2. Southwood, Med. J. Australia, Sydney, 1923, X, II, 460. (Quoted by Cori \& Cori, J. Biol. Chem., Baltimore, 1927, LXXXII, 615.)

3. Gilchrist, M. L., Glasgow Med. J., (In press).

4. Severinghaus, E. L., J. Biol. Chem., Baltimore, 1925, LXIII, 48.

5. Henderson, Y., Physiol. Rev., Baltimore, 1925, V, 131.

6. Field, H., \& Newburgh, L. H., J. Clin. Invest., Baltimore, 1927, IV, 447.

7. Langfeldt, E., J. Biol. Chem., Baltimore, 1921, XLVI, 381.

8. Du Vigneaud, V., Karr, W. G., Ibid., Baltimore, 1925, LXVI, 281.

9. Lennox, W. G., J. Clin. Irvest., Baltimore, 1927, IV, 331.

10. MacLean, H., \& De Wesselow, O. L. V., Quart. J. Med., Oxford, 1920-21, XIV, 103.

11. Haldane, G. B. S., Wigglesworth, V. B., \& Woodrow, C. F., Proc. Roy. Soc., London, 1924, B. XCVI, 1.

12. Shaffer, P. A., Medicine, Baltimore, 1923, II, 375.

13. Brown, M. J., \& Graham, G., Arch. Dis. Childh., London, 1926, I, 302.

14. Von Noorden, C., Metabolism and Practical Medicine, London, 1907, III, 1099.

15. Morris, N., \& Graham, S., Arch. Dis. Childh., London, 1927, II, 212.

16. Macleod, J. J. R., Physiol. Rev., Baltimore, 1924, IV., 21.

17. Ellis, R. W. B., Arch. Dis. Childh., London, 1931, VI, 285.

18. Stewart, G. N., \& Rogoff, I. M., Amer. J. Physiol., Baltimore, 1923, LXV, 318 \& 342.

19. MacCormick, N. A., Macleod, J. J. R., Noble, E. C., \& O’Brien, K., J. Physiol., Cambridge, 1925, LVII, 234.

20. Lawrence, R. D., Quart. J. Med., Oxford, 1926, XX, 69.

21. Mann, F. C., \& Magath, T. B. (Quoted by Mann, F. C., Medicine, Baltimore 1927, VI, 419.)

22. Burn, J. H., \& Marks, H. P., J. Physiol., Cambridge, 1925, LX, 131. 